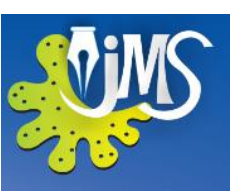

\title{
Frugivory of Yellow-eared Bulbul (Pycnonotus penicillatus) and Seasonal Variation of Fruiting Phenology in Tropical Montane Cloud Forests of Horton Plains National Park, Sri Lanka
}

\author{
Chandrasiri P.H.S.P and Mahaulpatha W.A.D* \\ Department of Zoology, University of Sri Jayewardenepura, Sri Lanka
}

\begin{abstract}
This study was conducted on a frugivorous bird species, Yellow-eared Bulbul (Pycnonotus penicillatus) which is an endemic and threatened species, at Horton Plains National Park (HPNP), from September 2015 to November 2017. Direct methods as focal animal sampling and faecal analysis were used to identify food items of P. penicillatus. Feeding plants were identified using field guides. To find out the fruit phenology, ten individuals per plant species were tagged. Fruit cover was estimated in the each tagged tree. According to the present findings, P. penicillatus mainly consumed, 16 species of feeding plants belonging to eleven families. Among them six endemic, eight native and one introduced species were observed. P. penicillatus consumed Rubus ellipticus as their major fruit source. There were seeds of nine plant species were identified by faecal analysis. Maximum ripen fruit cover was recorded from Solanum mauritianum in the northeast monsoon season, first inter-monsoon season and second intermonsoon season. However, in the southwest monsoon season highest ripen fruit cover was recorded from Berberis ceylanica. There was a correlation between number of feeding attempts and ripen fruit cover, of Symplocos bractealis, S. mauritianum and Strobilanthes viscosa. Moreover, there was a correlation between number of feeding attempts and number of trees in fruiting, of Elaeocarpus coreaceus, Passiflora tripartita, Eugenia mabaeoides and S. viscosa. The present study has revealed importance of the floral community to the P. penicillatus. Therefore, it is important to recommend monitoring protocols about the seasonal variations of fruiting phenology in and around HPNP, which are harbouring a large variety of feeding plants of the threatened birds species such as $P$. penicillatus for conservational purposes.
\end{abstract}

KEYWORDS: Frugivory, Yellow-eared Bulbul, Horton Plains National Park, Seasonal Variation, Tropical Montane Cloud Forest

Corresponding author: Mahaulpatha W.A.D., Email: mahaulpatha@sjp.ac.lk 


\section{INTRODUCTION}

Ecological interactions between plants and birds are the main phenomena of evolutionary aspects such as co-evolution. Therefore, interactions such as frugivory is an important role in the lives of many passerine birds (Estrada \& Fleming, 2012). Moreover, the term "frugivore" is used for the animals whose diets include a substantial portion of fruits at least during some seasons (Moermond \& Denslow, 1985). They usually consume fleshy fruits, including berries, drupes, pomes, aggregated fruits, multiple fruits, and accessory fruits(Lopes et $a l$, 2016).In many incidents fleshy fruits are eaten by birds, which obtain a reward as a result of digesting the pulp and take the seeds away from the parent plant to be later discarded in conditions suitable for germination (Herrera, 1984). Fruit-eating birds are distributed among a large variety of families of birds (Howe, 1986: Wheelwright, 1985). Only a few species of birds eat fruits throughout their lifetime (Moermond \& Denslow, 1985). Most of the birds complete their fruit diets with different, relatively protein-rich foods (Wheelwright, 1985), and those birds that do feed solely on fruits as adults usually feed insects to their juveniles (Moermond \& Denslow, 1985). Moreover, ability to digest fruit is believed to be an important limitation on the evolution of the interaction between plants bearing fleshy fruits and frugivorous birds (Herrera 1984). From previously studied 8918 terrestrial bird species a total of 1230 species (14\%) were classified as frugivorous and moreover, most frugivorous birds (50\%) are found within the perching birds (Passeriformes) (Kissling et al, 2009). Therefore, the role of passerines is a very important ecological role, especially as seed dispersal agents. Some researchers have found that small passerines dispersed most seeds within short distances (Jordano et al., 2007). Furthermore, phenology is the study of periodic plant and animal life cycle events and how these are influenced by seasonal and interannual variations in climate (Demarée, 2011).

Frugivory is a part of the diet of all bulbul species (Corlett, 1998). Fukui (1995) conducted laboratory experiments on the brown-eared bulbul Hypsypetes amaurotis by using 20 food plant species. The results demonstrated three phenomena. There were no seeds were injured by passing through the bulbul's gut. The seeds that had passed through the bulbul's gut were still able to germinate and fruit pulp has reduced germination ability. Other studies done on frugivory of bulbul species include nutritional analysis of frugivorous bulbuls have been carried out by Izhaki, (1992).

The Yellow-eared Bulbul (Passeriformes: Pycnonotidae), a bird species endemic to Sri Lanka, occurs in forest and nearby gardens, at middle and higher elevations, generally $900-2000 \mathrm{~m}$, where it is common to abundant in suitable habitats. It is an endemic threatened bird, assessed under IUCN global conservation status in the Near Threatened (NT) category, and according to the national conservation status $P$. penicillatus is categorized as a Vulnerable (VU) bird in the National Red List (MOE, 2012). Distribution of $P$. penicillatus throughout the country is already studied (Harrison \& Worfolk, 2011; MOE, 2012). Moreover, ecology about this species has generally studied in the history (Henry, 1998). Some other ecological aspects such as distribution (Chandrasiri \& Mahaulpatha, 2016) and 
foraging behaviour of $P$. penicillatus was studied recently by Chandrasiri \& Mahaulpatha (2017).

The present research was conducted in Tropical Montane Cloud Forests (TMCF) of Sri Lanka, at the Horton Plains National Park (HPNP) situated at Central highlands (Somasekaram, 1988). There is a significant change in the vegetation of highland forests in Sri Lanka at about $1,500 \mathrm{~m}$ elevation (Gunatilleke \& Pethiyagoda, 2012). Considering the specific characteristics of the vegetation, these forests are classified as Tropical Montane Cloud Forests (Aldrich et al., 1997). Canopies of the trees are well adapted to capture water from clouds, a phenomenon is known as cloud stripping. The amount of water reaching from the cloud stripping is higher than the water supply from rainfall (Gunatilleke \& Pethiyagoda, 2012). Furthermore, when compared with lowland rainforests, cloud forests can be easily distinguished by shorter canopy trees with gnarled branches, dense compact crowns; and small, closely- spaced, leathery, hard, waxy leaves. Moreover, the trees of the highland forests are closely spaced than those of lowland rain forests and soil is waterlogged, wet and highly organic (Hamilton et al., 1995). The forests of HPNP are dominated by the endemic Calophyllum walkeri in associated with many plant varieties of Myrtaceae and Lauraceae (Aldrich et al., 1997). This area is protected under the Department of Wildlife Conservation of Sri Lanka (Green, 1990).

Although, $P$. penicillatus is a common frugivore in the highlands of Sri Lanka (BirdLife International, 2016), there is a research gap and there is only a handful of information about their selection of feeding plants. Therefore, the present study was carried out to find out more detailed information about the fruiting plant preference and fruiting phenology of preferred plants of this endemic bird.

\section{MATERIALS AND METHODS}

The study area, HPNP is located at $6^{\circ} 47^{\prime}-$ $6^{\circ} 50^{\prime} \mathrm{N}, 80^{\circ} 46^{\prime}-80^{\circ} 50^{\prime} \mathrm{E}$ (Green, 1990) in Nuwara Eliya District. The HPNP occupies an area of 3,160 ha and contiguous with Peak Wilderness Sanctuary to the west (DWC, 2007; Pethiyagoda, 2012). Elevation of the HPNP ranges from $1800 \mathrm{~m}$ to $2389 \mathrm{~m}$ and Kirigalpota is the highest point (Aldrich et al., 1997). There are three main habitats at the HPNP, which were previously identified as: Cloud Forest, Cloud Forest Die-back and Grasslands (DWC, 2007). The Cloud Forest is distributed in an area of 1,236 ha with an undisturbed old-growth forest which is low in height $(15-20 \mathrm{~m})$ with compared to lowland rain forests(Ashton et al., 1997) and the canopy trees are characteristically gnarled and twisted, due to the lower temperatures and high winds. The Cloud Forest Die-back was distributed in an area of about 956 ha with the dead canopies. The type of habitat, which is considered as grassland contain mainly alpine flora of the montane grasslands locally known as 'wet pathana' (Gunatilleke \& Gunatilleke, 1990). This habitat contains Dwarf Bamboo, Tussock Grass and Carpet Grass (DWC, 2007). Grassland habitat is distributed in an area of 806 ha of the National Park. The present research was conducted from September 2015 to November 2017 in three consecutive days per month.

Previously Chandrasiri and Mahaulpatha (2016) has reported that, Cloud Forest and Cloud Forest Die-back were the main 
habitats occupied by the Yellow-eared Bulbul. Furthermore, Chandrasiri and Mahaulpatha (2017) has mentioned that, maximum number of foraging observations (95\%) were recorded from the forest habitat and only $5 \%$ were recorded from grassland habitat. Within first three months a preliminary study was carried out to plot the feeding areas and observation of feeding plants of P.penicillatus. Moreover, this study was limited to the forest habitats where the cloud forest habitat and cloud forest die-back habitat were situated. Nine, $100 \mathrm{~m}$ fixed line transacts of $20 \mathrm{~m}$ width, were geolocated in the forest habitats by using a global positioning system device (GPS- Garmin eTrex 20x). In the preliminary study from September 2015 to November 2015, typical field notes, or "Ad Lib. Sampling" (Altman, 1974) was carried out to find out foraging attempts of the bird. From December 2015 to November 2017, focal animal sampling method was carried out to record the number of feeding attempts and at the meantime the particular plant species was identified by observing through a pair of binoculars (Nikon Monarch ${ }^{\mathrm{TM}}$ $10 \times 50$ ). To ascertain the feeding plants, faecal sampling methods were carried out. Fruit trees where the feeding behaviour was observed, were identified to the species level using field guides (Ashton et al, 1997). Faecal samples which were collected at the field were immediately stored in $70 \%$ ethanol and preserve for further laboratory studies. At the laboratory, the samples were analysed and the seeds observed were separated using a modified petri dish (Green \& Tyler, 1989) and these seeds were observed under a binocular microscope
(Olympus $^{\mathrm{TM}}$ CX31), and identified using reference collections. To find out the fruiting phenology, ten individuals per each identified plant species were geolocated by the GPS. All the ripen fruits were observed through a spotting scope (Nikon Monarch ${ }^{\mathrm{TM}}$ 20-60x82 ED) in three branches from each tagged tree. This method was carried out in every month and ripen fruit percentage was estimated (Wheelwright, 1985). Monthly observations were summarized in to seasonal data. The weather conditions experienced during a 12-month period were characterized into four climate seasons according to Chandrapala (1996). These seasons were identified as: first intermonsoon season (March- April), southwestmonsoon season (May-September), second inter-monsoon season (October-November) and northeast-monsoon season (DecemberFebruary).

Data were analysed using Microsoft Excel $^{\mathrm{TM}}$. Since the data were nonparametric, Spearman Rank Correlation was calculated in Minitab-17 ${ }^{\mathrm{TM}}$. The results were considered significant at $\alpha=0.05$. The correlation between number of feeding attempts and ripen fruit cover and the correlation between number of feeding attempts and number of trees in fruiting was calculated.

\section{RESULTS}

According to the present data, $P$. penicillatus has mainly consumed, sixteen species of feeding plants belonging to ten families, which are further described in following table 1 . 
Table 1. A description of feeding plant species of P. penicillatus

\begin{tabular}{llll}
\hline Plant Species & Family & Origin & Habit \\
\hline Rubus ellipticus & Rosaceae & Native & Shrub \\
\hline Solanum mauritianum & Solanaceae & Native & Shrub \\
\hline Symplocos bractealis & Symplocaceae & Endemic & Tree \\
\hline Sarcococca brevifolia & Buxaceae & Native & Tree \\
\hline Rhodomyrtus tomentosa & Myrtaceae & Native & Shrub to small tree \\
\hline Rubus leucocarpus & Rosaceae & Native & Shrub \\
\hline Passiflora tripartita & Passifloraceae & Introduced & Vine \\
\hline Berberis ceylanica & Berberidaceae & Endemic & Shrub \\
\hline Cestrum fasciculatum & Solanaceae & Introduced & Shrub \\
\hline Elaeocarpus coreaceus & Elaeocarpaceae & Native & Tree \\
\hline Solanum lasiocarpum & Solanaceae & Native & Shrub \\
\hline Rubus indicus & Rosaceae & Native & Shrub \\
\hline Callophyllum walkeri & Guttiferae & Endemic & Tree \\
\hline Syzygium rotundifolium & Myrtaceae & Endemic & Tree \\
\hline Eugenia mabaeoides & Myrtaceae & Endemic & Shrub to small tree \\
\hline Strobilanthes viscosa & Acanthaceae & Endemic & Shrub \\
\hline
\end{tabular}

Among them six species are endemic to Sri Lanka. Eight species of them are native plants. Moreover, they consumed Passiflora tripartite (Plate 3), which was introduced to
Sri Lanka. These fruits were distributed in every layer of the forest from shrub to trees. Many of the plant species were distributed within the shrubs profile. (Figure 1).

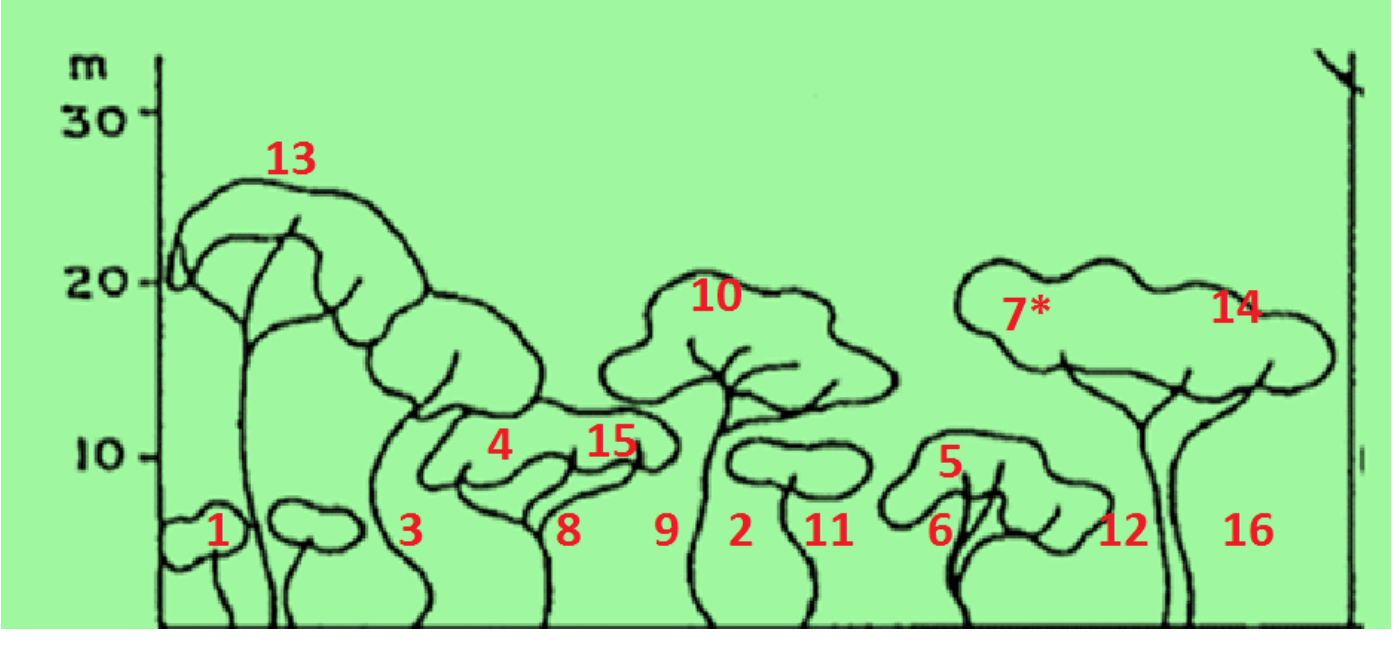

1-Rubus ellipticus,2-Solanum mauritianum,3-Symplocos bractealis,4-Sarcococca brevifolia, 5-Rhodomyrtus tomentosa,6-Rubus leucocarpus,7-Passiflora tripartita,8-Berberis ceylanica,9-Cestrum fasciculatum,10Elaeocarpus coreaceus, 11-Solanum lasiocarpum,12-Rubus indicus,13-Callophyllum walkeri,14-Syzygium rotundifolium,15-Eugenia mabaeoides,16-Strobilanthes viscosa, * vines- distributed in the canopy level

Figure 1. Vegetation profile within Tropical Montane Cloud Forests of Horton Plains National Park (Modified diagram from Ashton et al., 1997) 


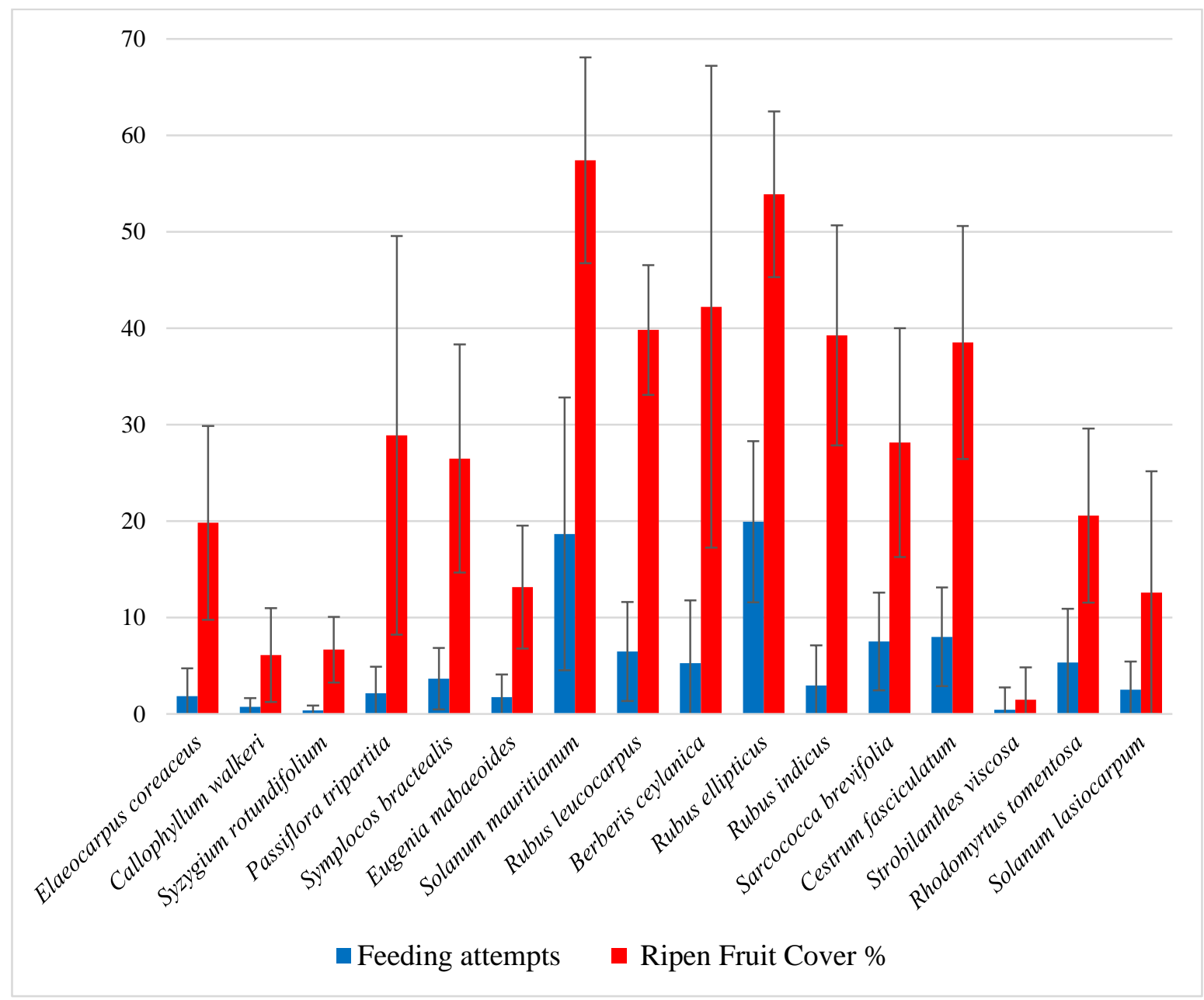

Figure 2. Feeding attempts of $P$. penicillatus

$P$. penicillatus preferred $R$. ellipticus as its major fruit source (Figure 2). The overall maximum number of feeding attempts (Plate $01)$ were recorded by $R$. ellipticus $\{19.93 \pm$ 8.35 (Mean \pm Standard Deviation) $\}$ during the study period. Moreover, S. mauritinum (Plate 2) is consumed to a considerable extent 18.67 $\pm 14.14(\mathrm{M} \pm \mathrm{SD})\}$. During most of their feeding attempts, C. fasciculatum (Plate 4) $\{8.00 \pm 5.11(\mathrm{M} \pm \mathrm{SD})\}$ and $S$. brevifolia $\{7.52 \pm 5.06(\mathrm{M} \pm \mathrm{SD})\}$ were consumed. Foraging fruits within other plant species such as $R$. leucocarpus, $R$. tomentosa, B. ceylanica and $S$. bractealis were also observed in higher values in the field. 


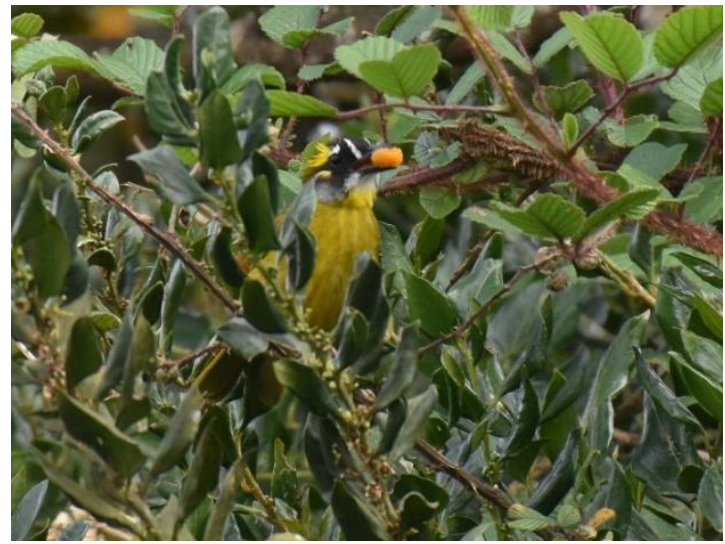

Plate 1. P. penicillatus is feeding on a $R$. ellipticus fruit

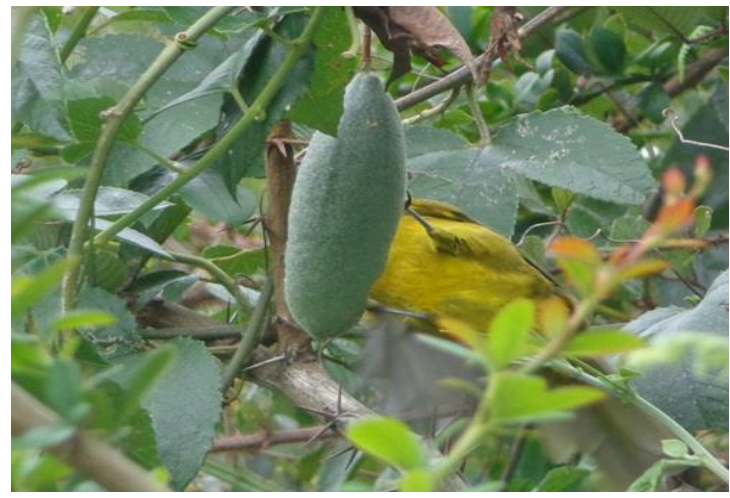

Plate 3. $P$. penicillatus is feeding on a $P$. tripartita fruit fruit

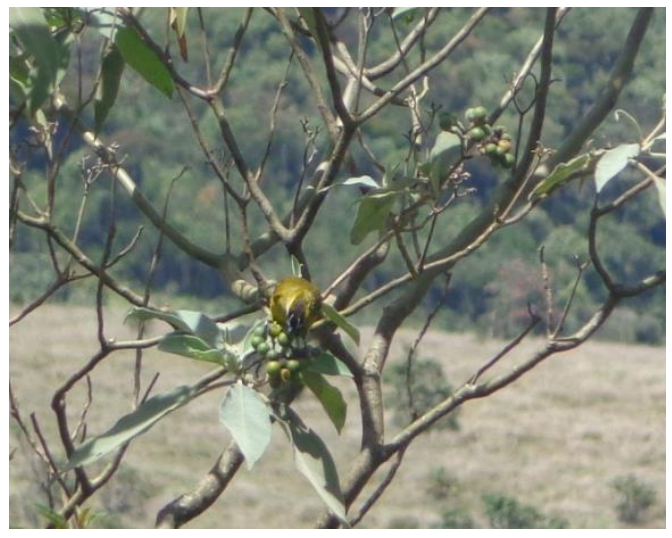

Plate 2. P. penicillatus is feeding on a $S$. mauritinum fruit

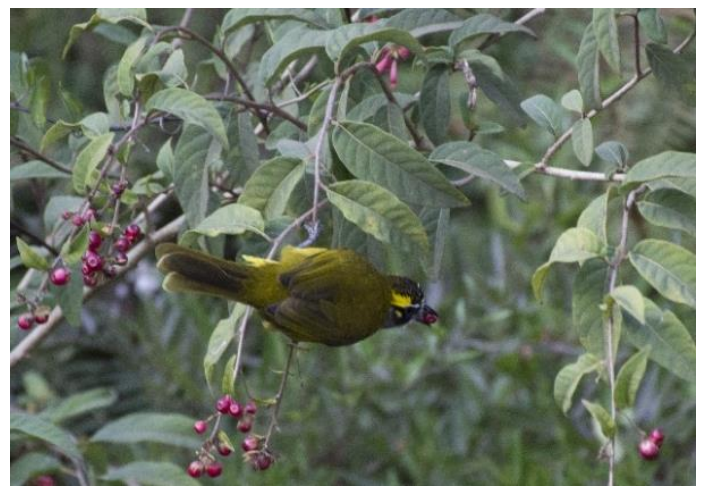

Plate 4. P. penicillatus is feeding on a C. fasciculatum

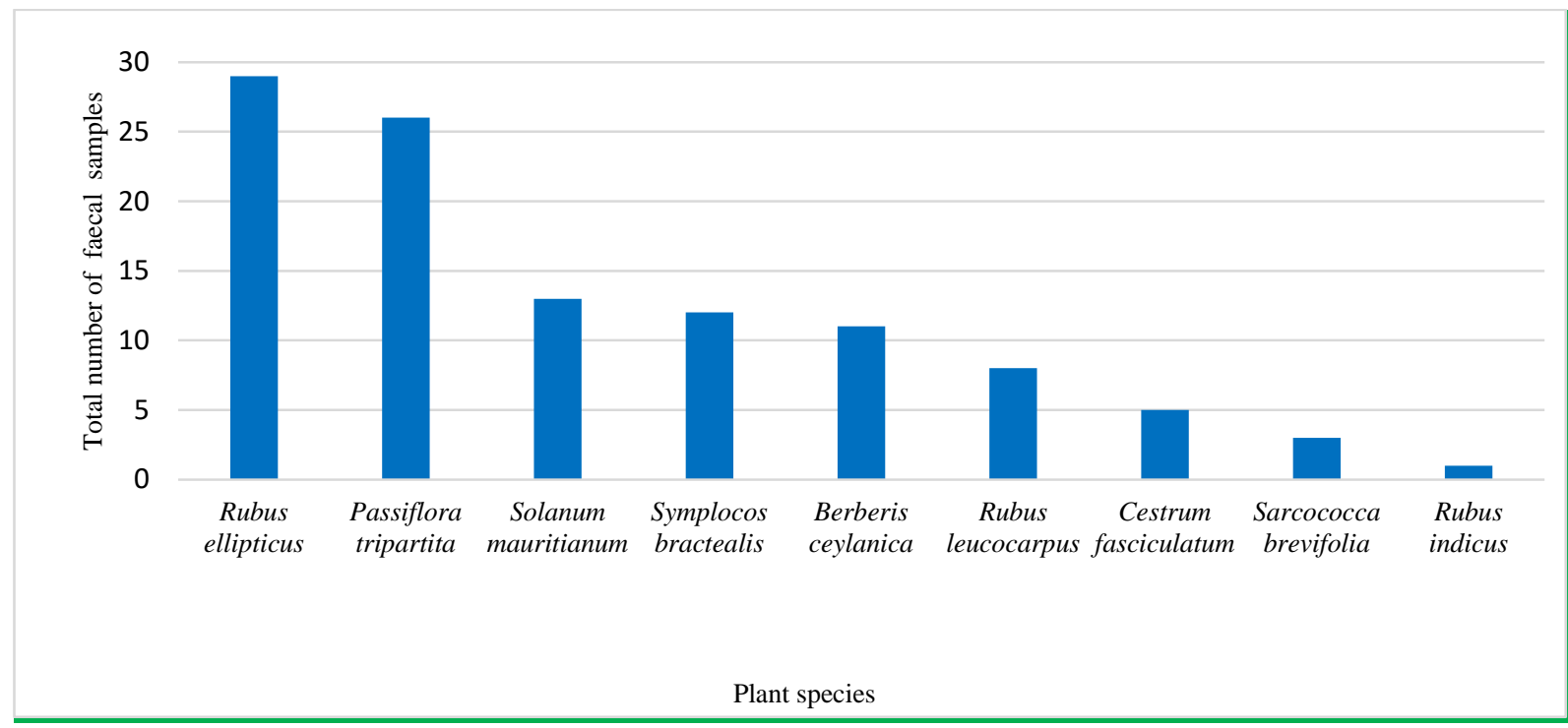

Figure 3. Food plants of $P$. penicillatus revealed by the presence of seeds in the faecal samples 
Within the study 108 faecal samples were collected (Figure 3). Seeds of nine plant species were identified in the laboratory. Maximum number of samples were contented with $R$. ellipticus and $P$. tripatrita.

Furthermore, S. mauritianum, $S$. bractealis, $B$. ceylanica, $R$. leucocarpus and $C$. fasciculatum were observed to a lesser extent, respectively. $S$. brevifolia and $R$. indicus were recorded in the least number of the faecal samples.

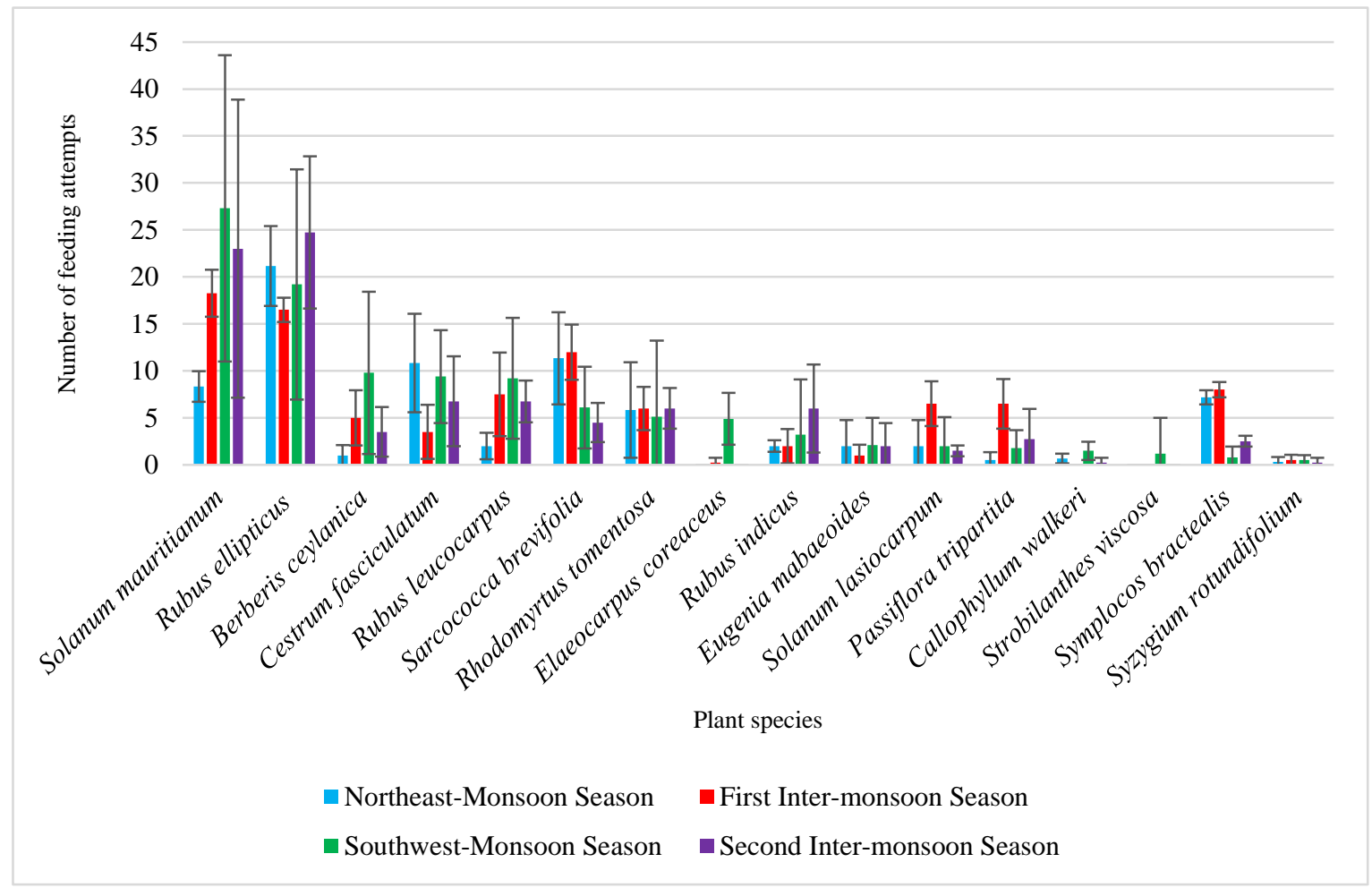

Figure 4. Seasonal variation of feeding attempts of $P$. penicillatus on different plant species

The $P$. penicillatus was feeding on 13 plant species within the four seasons (Figure 4). In the northeast monsoon season $\{21.16 \pm 4.26$ $(\mathrm{M} \pm \mathrm{SD})\}$ and second inter-monsoon season $\{24.75 \pm 8.0984 \quad(\mathrm{M} \pm \mathrm{SD})$ they highly consumed $R$. ellipticus. In the first inter- monsoon season $\{18.25 \pm 2.5(\mathrm{M} \pm \mathrm{SD})\}$ and southwest monsoon season $\{27.3 \pm 16.31$ $(\mathrm{M} \pm \mathrm{SD})\}$, S. mauritianum was the major feeding plant. 


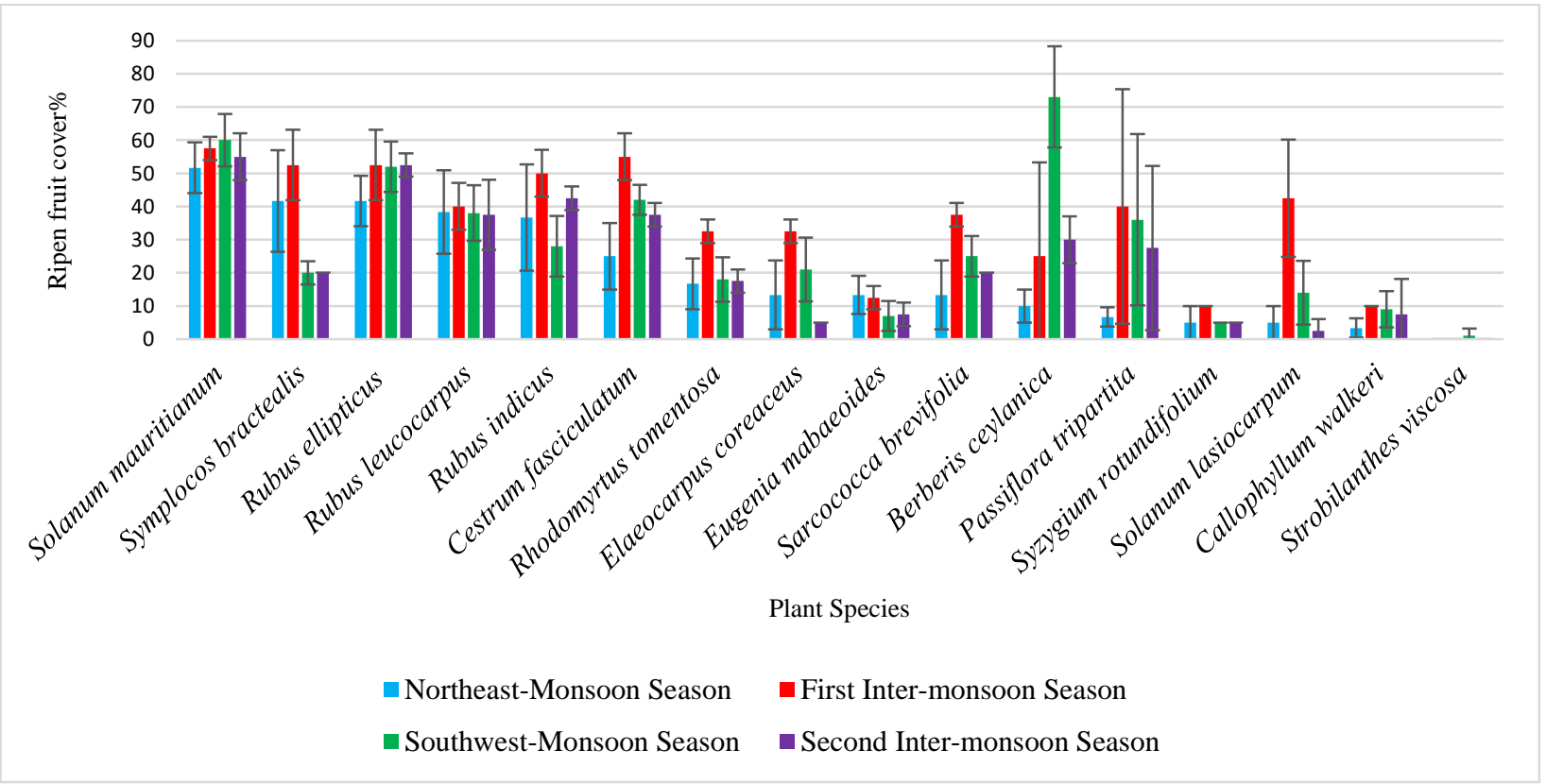

Figure 5. Seasonal variation of ripen fruit cover \% of different plant species

The maximum ripen fruit cover was recorded highest ripen fruit cover was recorded from $B$. from $S$. mauritianum (Figure 5) during the ceylanica $\{73 \pm 15.24795068(\mathrm{M} \pm \mathrm{SD})$. The northeast monsoon season $\{51.67 \pm 7.64$ ripen fruit cover of $S$. viscosa $\{1.0 \pm 2.2$ $(\mathrm{M} \pm \mathrm{SD})\}$, first inter-monsoon season $(\mathrm{M} \pm \mathrm{SD})\}$ which is less significant, was $\{57.5 \pm 3.54(\mathrm{M} \pm \mathrm{SD})\}$ and second inter- observed only at southwest-monsoon Season. monsoon season $\{55 \pm 7.07 \quad(\mathrm{M} \pm \mathrm{SD})$. All the plant species had ripen fruits in every However, in the southwest monsoon season seasons except $S$. viscosa (Figure 6).

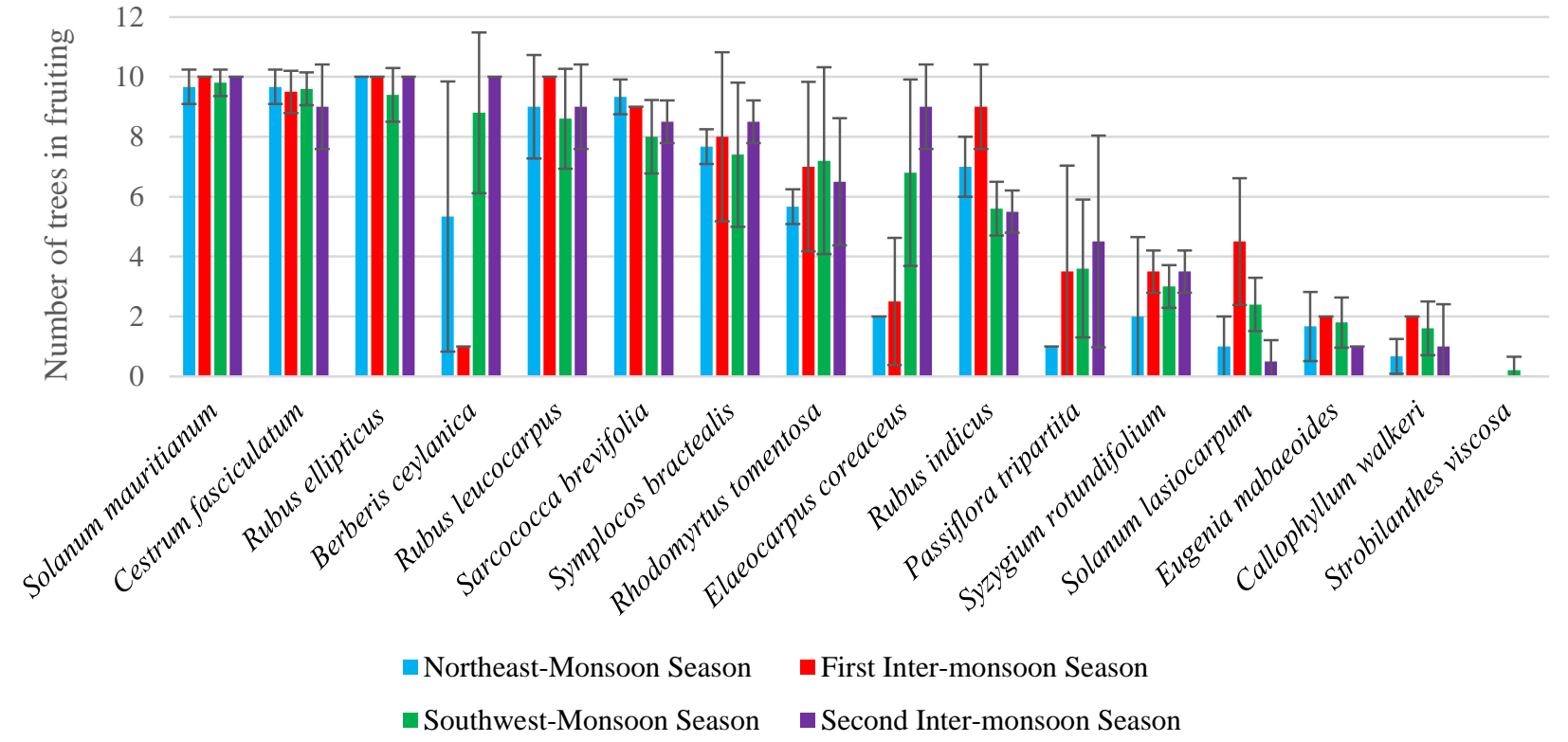

Figure 6. Seasonal variation of trees in fruiting of different plant species 
Table 2. Correlation between the number of feeding attempts and ripen fruit cover

\begin{tabular}{lllll}
\hline Plant Species & $\begin{array}{l}\text { Spearman Rank Correlation } \\
\text { between number of feeding } \\
\text { attempts and ripen fruit } \\
\text { cover }\end{array}$ & $p$-value & $\begin{array}{l}\text { Spearman Rank Correlation } \\
\text { between number of feeding } \\
\text { attempts and number of trees } \\
\text { in fruiting }\end{array}$ & $p$-value \\
\hline Elaeocarpus coreaceus & 0.277 & 0.162 & 0.463 & $0.015^{*}$ \\
\hline Syzygium rotundifolium & 0.277 & 0.163 & 0.238 & 0.233 \\
\hline Passiflora tripartita & 0.361 & 0.064 & 0.487 & $0.010^{*}$ \\
\hline Symplocos bractealis & 0.403 & $0.037 *$ & 0.010 & 0.960 \\
\hline Eugenia mabaeoides & 0.213 & 0.287 & 0.380 & $0.050^{*}$ \\
\hline Solanum mauritianum & 0.551 & $0.003^{*}$ & 0.218 & 0.275 \\
\hline Solanum lasiocarpum & 0.230 & 0.249 & 0.263 & 0.185 \\
\hline Rubus leucocarpus & 0.292 & 0.139 & 0.340 & 0.083 \\
\hline Berberis ceylanica & 0.320 & 0.104 & 0.236 & 0.236 \\
\hline Rubus ellipticus & -0.014 & 0.945 & 0.324 & 0.099 \\
\hline Rubus indicus & 0.229 & 0.250 & 0.141 & 0.484 \\
\hline Sarcococca brevifolia & -0.030 & 0.884 & 0.303 & 0.125 \\
\hline Cestrum fasciculatum & -0.049 & 0.809 & 0.294 & 0.136 \\
\hline Strobilanthes viscosa & 0.452 & $0.018^{*}$ & 0.452 & $0.018^{*}$ \\
\hline Rhodomyrtus tomentosa & 0.321 & 0.102 & 0.272 & 0.170 \\
\hline Callophyllum walkeri & 0.263 & 0.185 & 0.325 & 0.099 \\
\hline
\end{tabular}

* $p$-value $<0.05=$ there is a significant association between variables

There was a positive correlation between number of feeding attempts and ripen fruit cover, of $S$. bractealis (Spearman Rank Correlation $=0.403, p$-value $=0.037), S$. mauritianum (Spearman Rank Correlation=0.551, $p$-value $=0.003$ ) and $S$. viscosa (Spearman Rank Correlation $=0.452$, $p$-value $=0.018$ ). Moreover, there was a correlation between number of feeding attempts and number of trees in fruiting, of E. coreaceus (Spearman Rank Correlation $=0.463, \quad p$-value $=0.015), \quad P$. tripartita (Spearman Rank Correlation=0.487, $p$-value $=0.010), \quad E$. mabaeoides (Spearman Rank Correlation=0.380, $p$-value $=0.010)$ and $S$. viscosa (Spearman Rank Correlation $=0.452$, $p$-value $=0.018)$.

\section{DISCUSSION}

Both the direct observations and faecal analysis methods, confirmed that ripen fruits of $R$. ellipticus was the major food of $P$. penicillatus. It is a common scenario that the brambles of genus Rubus are common in high elevations above $1500 \mathrm{~m}$ and that many species of birds feed on ripen berries. Most members of this family are shrubs or small trees, and their fruits are small and succulent. Therefore, they provide food for the smaller, comparatively unspecialized frugivores (Snow, 1981). In this study three important bramble species (R.ellipticus, $R$. leucocarpus and Rubus indicus) were identified as food sources of $P$. penicillatus. One variety of bramble $R$. leucocarpus var. leucocarpus is endemic to Sri Lanka. These brambles are commonly distributed in the highlands of Sri Lanka, and it has been reported previously that they form a crucial part of diet of the birds (Pethiyagoda, 2012).

The bulbuls highly consumed fruits of endemic plants such as $S$. bractealis, $B$. ceylanica, C. walkeri, S. rotundifolium and 
E. mabaeoides since those plants are abundant in the forest habitat (DWC, 2007). However, it has been observed $P$. penicillatus feeding on $P$. tripartita (banana passion fruit) which is an introduced plant species now classified under invasive species by Weber (2017). They can smother forest margins and forest regrowth (Weber, 2017) therefore in the future this plant species will be a threat to the growth of other plants at HPNP. According to the results of the present study $P$. penicillatus is mostly feeding on endemic and native plants. Therefore, eradication of $P$. tripartita will not affected the feeding ecology of $P$. penicillatus. Furthermore, Davis (2011) has mentioned that, the birds do not care whether their fruit sources are native or exotic.

In the faecal sample analysis, there were no multiple seed types recorded from any faecal sample. This may be due to the fact that birds mostly attempt to fulfil their dietary needs from one fruit plant during a single feeding bout. The Yellow-eared Bulbul has a wide range of fruits, distributed in every stratum of the forest, ranging from the bushes, which belong to the understory, and some trees (C. walkeri) belong to emergent layer (Ashton et al, 1997).

Most species of the plants had ripen fruit throughout the year. This is a great opportunity to tropical frugivorous birds such as $P$. penicillatus. Compared with the temperate highlands most fruits are unavailable from April to August (Herrera, 1984). However, the tropical highlands have ripen fruits throughout every season of the year (Kitamura et al., 2002). Therefore, they had sufficient amount of fruit supply within four seasons to fulfil their diet. Thus, they do not need to migrate over long distances to find food.

The results of significant correlation between number of feeding attempts and ripen fruit cover, of $S$. bractealis, and $S$. mauritianum should be because of these plants are commonly distributed in the forest habitats (DWC, 2007). However, the correlation with $S$. viscosa has also recorded in this study. This may be because of the seasonal availability of the fruits of this Nelu species in every year. It is different from the other Strobilanthes species, which the $S$. viscosa is flowering annually. Furthermore, there was a correlation between number of feeding attempts and number of trees in fruiting, of E. coreaceus, P. tripartita, E. mabaeoides and S. viscosa. These plants had seasonal variation of fruiting phenology.

These researches are useful for ecological studies. Since the tropical forest systems are being rapidly transformed into commercial plantations and farmlands (Chapman et al., 2005). Therefore, it is important to recommend long term monitoring of the seasonal variations of fruiting phenology in and around HPNP, as recommended by Newbery et al. (1998). The area harbours a large variety of feeding plants of the threatened birds such as $P$. penicillatus. Furthermore, the Yellow- eared Bulbuls may act as an important seed dispersal agent in the tropical montane cloud forests of HPNP. Therefore, construction of phenology calendars is recommended for the protection of floral community in the habitats, as recommended by Sulistyawati, et al. (2012). Appropriate attention of the authorities is important, and it would benefit and enhance the quality of the forest management strategies. 


\section{ACKNOWLEDGEMENT}

Financial assistance provided by the University of Sri Jayewardenepura (Grant Number ASP/01/RE/SCI/2015/34) is acknowledged. The authors also wish to thank the Department of Wildlife Conservation for granting permission to carry out this study in Horton Plains National Park (Permit No WL/3/2/13/15), IDEA WILD organization, the staff of Horton Plains National Park, the research crew of Wildlife Circle, Department of Zoology University of Sri Jayewardenepura and the Department of English University of Sri Jayewardenepura for their assistance in various ways.

\section{REFERENCES}

Aldrich, M., Billington, C., Edwards, M. and Laidlaw, R., 1997. Tropical montane cloud forests: an urgent priority for conservation. WCMC Biodiversity Bulletin, 2, pp.1-14.ALTMANN J, Observational study of behaviour: Sampling methods. Behaviour1974; 49: 227-267.

Ashton, M.S., Gunatilleke, S., De Zoysa, N., Dassanayake, M.D., Gunatilleke, N. and Wijesundera, S., 1997. A field guide to the common trees and shrubs of Sri Lanka (p. 430). Colombo, Sri Lanka: WHT Publications.

Birdlife International 2016. Pycnonotus penicillatus. The IUCN Red List of Threatened Species 2016: e. T22712722A94345457. http://dx.doi.org/10.2305/IUCN.UK.20163.RLTS. T22712722A94345457.en. Downloaded on 28 July 2019.
Chandrapala, L., 1996. Long term trends of rainfall and temperature in Sri Lanka. Climate variability and agriculture, pp.153-162.

Chandrasiri, P.H.S.P. and Mahaulpatha, W.A.D, 2016. Distribution of Sri Lanka Yellow-eared Bulbul (Pycnonotus penicillatus) in Tropical Montane Cloud Forest-Horton Plains National Park., Proceedings of the 3rd International Conference on Multidisciplinary Approaches, Faculty of Graduate, University of Sri Jayewardenepura, Nugegoda, Sri Lanka. 2016;3:3

Chandrasiri, P.H.S.P. and Mahaulpatha, W.A.D. Foraging Behaviour of Sri Lanka Yellow-eared Bulbul (Pycnonotus penicillatus) in the Montane Cloud Forests of Horton Plains National Park, Sri Lanka. International Journal of Science and Research (IJSR). 2017;6:695-699.

Chapman, C.A., Chapman, L.J., Struhsaker, T.T., Zanne, A.E., Clark, C.J. and Poulsen, J.R., 2005. A long-term evaluation of fruiting phenology: importance of climate change. Journal of Tropical ecology, 21(1), pp.31-45.

Corlett, R.T., 1998. Frugivory and seed dispersal by vertebrates in the Oriental (Indomalayan) Region. Biological reviews, 73(4), pp.413-448.

Davis, M., 2011. Do native birds care whether their berries are native or exotic? No. BioScience, 61(7), pp.501-502.

Demarée, G.R., 2011. From "Periodical Observations" to "Anthochronology" and "Phenology"-the scientific debate between 
Adolphe Quetelet and Charles Morren on the origin of the word "Phenology". International journal of biometeorology, 55(6), pp.753-761.

DWC. 2007. Biodiversity Baseline Survey: Horton Plains National Park. Department of Wildlife Conservation, Ministry of Environment and Natural Resources, Colombo.

Estrada, A. and Fleming, T.H. eds., 2012. Frugivores and seed dispersal (Vol. 15). Springer Science \& Business Media.

Fukui, A.W., 1995. The role of the browneared bulbul Hypsypetes amaurotis as a seed dispersal agent. Population Ecology, 37(2), pp.211-218.

Green, M.J.B. ed., 1990. IUCN directory of South Asian protected areas. IUCN.

Green, R.E. and Tyler, G.A., 1989. Determination of the diet of the stone curlew (Bwhinus oedicnemus) by faecal analysis. Journal of Zoology, 217(2), pp.311-320.

Gunatilleke, I.A.U.N. and Gunatilleke, C.V.S., 1990. Distribution of floristic richness and its conservation in Sri Lanka. Conservation Biology, 4(1), pp.2131.

Gunatilleke C.V.S., Pethiyagoda R., 2012. Cloud forest. Horton Plains. In Sri Lanka's cloud forest national park, Pethiyagoda R. editor. WHT, Colombo, p78-139.

Hamilton, L.S., Juvik, J.O. and Scatena, F.N., 1995. The Puerto Rico tropical cloud forest symposium: introduction and workshop synthesis. In Tropical montane cloud forests (pp. 1-18). Springer, New York, NY.

Harrison, J., 2011. A field guide to the birds of Sri Lanka. Oxford University Press.

Henry, G.M., 1998. A guide to the birds of Sri Lanka. Oxford University Press, USA.

Hoffmann, T.W., Warakagoda, D. and Ekanayake, U., 1998. A guide to the birds of Sri Lanka. Oxford University Press.

Herrera, C.M., 1984. A study of avian frugivores, bird-dispersed plants, and their interaction in Mediterranean scrublands. Ecological monographs, 54(1), pp.1-23.

Howe, H.F., 1986. Seed dispersal by fruiteating birds and mammals. Seed dispersal, 123, p.189.

Izhaki, I., 1992. A comparative analysis of the nutritional quality of mixed and exclusive fruit diets for yellow-vented bulbuls. The Condor, 94(4), pp.912-923.

Jordano, P., García, C., Godoy, J.A. and García-Castaño, J.L., 2007. Differential contribution of frugivores to complex seed dispersal patterns. Proceedings of the National Academy of Sciences, 104(9), pp.3278-3282.

Daniel Kissling, W., Böhning-Gaese, K. and Jetz, W., 2009. The global distribution of frugivory in birds. Global Ecology and Biogeography, 18(2), pp.150-162.

Kitamura, S., Yumoto, T., Poonswad, P., Chuailua, P., Plongmai, K., Maruhashi, T. and Noma, N., 2002. Interactions between fleshy fruits and frugivores in a tropical 
seasonal forest in

Thailand. Oecologia, 133(4), pp.559-572.

MOE. 2012;8. The National Red List of Sri Lanka; Conservation Status of the Fauna and Flora. Ministry of Environment, Colombo, Sri Lanka.

Moermond, T.C. and Denslow, J.S., 1985. Neotropical avian frugivores: patterns of behavior, morphology, and nutrition, with consequences for fruit selection. Ornithological Monographs, pp.865-897.

Newbery, D.M., Songwe, N.C. and Chuyong, G.B., 1998. 11. PHENOLOGY AND DYNAMICS OF AN AFRICAN RAINFOREST AT KORUP, CAMEROON. In Dynamics of tropical communities: 37th Symposium of the British Ecological Society (p. 267). Cambridge University Press.

Pethiyagoda, R. and Wildlife Heritage Trust of Sri Lanka, 2012. Horton Plains: Sri Lanka's cloud-forest national park. Wildlife Heritage Trust.

Snow, D.W., 1981. Tropical frugivorous birds and their food plants: a world survey. Biotropica, pp.1-14.

Somasekaram, T., 1988. The National Atlas of Sri Lanka. Sri Lanka Survey Department: Colombo, Sri Lanka, pp.1-141.

Sulistyawati, E., Mashita, N., Setiawan, N.N., Choesin, D.N. and Suryana, P., 2012. Flowering and fruiting phenology of tree species in mount papandayan nature reserve, West Java, Indonesia. Tropical life sciences research, 23(2), p.81.
Weber, E., 2017. Invasive plant species of the world: a reference guide to environmental weeds. Cabi.

Wheelwright, N.T., 1985. Fruit-size, gape width, and the diets of fruit-eating birds. Ecology, 66(3), pp.808-818. 